\title{
BIOEDUSCIENCE
}

ISSN: 2614-1558

http://journal.uhamka.ac.id/index.php/bioeduscience

\section{Nipah Resistant Starch (Nypa fruticans): Modulation of Normal Microflora of Digestion, and Control of Diabetes}

\author{
Vanya Aulia1, Pellya Pachira1, Monika Olvi'1, Cico Jhon Karunia Simamora2*
}

1Food Science and Technology Study Program, Faculty of Agriculture, Tanjungpura Pontianak University, Jl. Hadari Nawawi, Pontianak, Indonesia, 78124

${ }^{2}$ Agrotechnology Study Program, Faculty of Agriculture, Tanjungpura Pontianak University, Jl. Hadari Nawawi, Pontianak, Indonesia, 78124

*Correspondent Email: csomamora@faperta.untan.ac.id

\section{ARTICLE INFO}

Article history:

Received: 29 Apr 2021

Accepted: 09 Agt 2021

Published: 31 Dec 2021

\section{Keywords:}

Blood Sugar levels;

Prebiotics;

Probiotics;

\section{A B S T R A C T}

Background: Gut microbiota in people with diabetes is unstable, and sufferers need foods low in calories to not raise blood sugar levels drastically. Nipah grown in coastal areas has a reasonably high starch content, potentially a source of resistant starch that a beneficial colon microbiota can ferment. The purpose of writing this review is to expand knowledge and provide information to the broader community regarding the potential of Nipah, which can be used as a source of new resistant starch that can be used in diabetes and modulation of normal microflora of the body. Method: This review writing procedure is done by searching various literature electronically, namely accessing International and National article searches and books through databases such as Google Scholar, ScienceDirect, and others. The collected data is then processed using Mendeley and then synthetic with narrative methods to conclude (interpretation). Results: Results in the writing of this review, namely obtained Nipah fruit flour with a high enough starch content, which is $35.66 \%$, which has the potential as a source of resistant starch. Conclusion: The writing of this review is that the high content of Nipah starch can be developed into a cheap, resistant starch innovation specifically for people with diabetes.

\section{Nipah Resistant Starch (Nypa fruticans), Modulasi Mikroflora Normal Pencernaan dan Pengendalian Diabetes}

\section{A B S T R A K}

\section{Kata kunci:}

Kadar gula darah;

Prebiotik;

Probiotik;
Background: Mikrobiota usus pada penderita diabetes, jumlahnya dalam kondisi yang tidak seimbang dan penderita cenderung memerlukan makanan yang rendah kalori seingga tidak menaikkan kadar gula darah secara drastis. Nipah yang tumbuh di daerah pesisir memiliki kandungan pati cukup tinggi, berpotensi sebagai sumber pati resisten yang dapat difermentasi oleh mikrobiota usus besar yang menguntungkan. Tujuan penulisan review ini adalah untuk memperluas pengetahuan dan memberikan informasi kepada masyarakat luas terkait potensi nipah yang bisa dijadikan sebagai sumber pati resisten baru yang dapat digunakan dalam pengendalain diabetes dan modulasi mikroflora normal tubuh. Metode: Prosedur penulisan review ini dilakukan dengan mencari berbagai literatur secara elektronik yaitu mengakses pencarian artikel Internasional dan Nasional serta buku melalui database seperti Google Scholar, ScienceDirect, dan lain-lain. Data yang terkumpul kemudian diolah menggunakan Mendeley lalu di sintetis dengan metode naratif untuk menarik kesimpulan (interprestasi). Hasil: Hasil dalam penulisan review ini, yaitu diperoleh tepung buah nipah dengan kandungan pati cukup tinggi, yaitu 35,66\%, yang berpotensi sebagai sumber pati resisten. Kesimpulan: Penulisan review ini adalah kandungan pati nipah yang tinggi sangat berpotensi dikembangkan menjadi inovasi pati resisten murah khusus bagi penderita diabetes. 


\section{Introduction}

Diabetes is a class of metabolic diseases characterized by the formation of hyperglycemia that occurs due to disruptions in insulin secretion, insulin work or both (American Diabetes Association, 2013). Many treatments for diabetes, mainly type 2 diabetes, such as. Dietary therapy, oral antidiabetic drugs and insulin, and oral administration (pharmacological treatment) can cause side effects (Lau, Harper et al., 2008). In addition, nonpharmacological therapy through dietary regulation is also effective at controlling blood glucose levels, lipid profiles, and blood pressure in people with type 2 diabetes. Nevertheless, the behaviour of diabetics is often challenging to go on a sugar diet. Therefore, innovations are needed to create food that does not raise blood sugar levels.

Prebiotics are indigestible foodstuffs but can stimulate the growth of beneficial gut microbiota in the large intestine and suppress the activity of harmful bacteria in the host (Zaman \& Sarbini, 2016). The gut microbiota plays a vital role in the digestive system, including supplying essential nutrients, aiding digestion and improving a healthy digestive system (Rengadu et al., 2020). Intestinal microbiota stimulated by prebiotics can prevent or treat some diseases and indigestion (Zhang et al., 2015). One ingredient that can improve digestive and intestinal health and act as a prebiotic is resistant starch (Rengadu et al., 2020).

Resistant starch (RS) is a component of complex carbohydrates and prebiotics that is relatively resistant to hydrolysis of stomach acid and cannot be digested in the small intestine by enzymes $\alpha$-amylase produced by the pancreas gland (Microbiome et al., 2017; Setiarto et al., 2018). RS has many health benefits, such as having no calories, not raising blood glucose, but it has physiological effects similar to dietary fibre (Rengadu et al., 2020). In addition, rs can also be fermented by good beneficial bacteria in the gut (Johnson \& Southgate, 1994). That is what makes the hospital has the potential as good functional food for people with diabetes. Rs consumption may affect insulin sensitivity in healthy individuals and those with metabolic syndrome (Bodinham et al., 2014). Thus, the hospital has the opportunity to be used as a type 2 diabetes therapy (Everard \& Cani, 2013; Bodinham et al., 2014). Resistant starch can be processed from various food sources with a high starch content, such as rice starch (Shi \& Gao, 2011), corn starch (Ozturk et al., 2011), cassava starch (Onyango et al., 2006), banana starch (Nasrin \& Anal, 2014) and barley starch (Kim et al., 2013). One plant that has the potential as a resistant starch is Nipah. Nipah Nypa fruticans) in Indonesia, especially on the coast of Kalimantan, the number is quite melipah.

Nipah is widely used by the coastal community of Peraian Banyuasin South Sumatra as a traditional medicinal ingredient in stomach pain medicine, diabetes and deep heat-lowering drugs (Ulyarti et al., 2017). Sahoo et al. (2012) reported that Nipah has bioactive content such as saponins, flavonoids and tannins that can be used as biopharmaceutical raw materials, as stated by Ulyarti et al. (2017). In addition, the results of the study by Ulyarti et al. (2017) also showed that Nipah fruit could be used as flour, with a high enough starch content, which is $35.66 \%$. The high total starch of Nipah fruit indicates that this Nipah origin starch can source resistant starch. Resistant starch itself is known to be unable to absorb the small intestine. The unprocessed form of rs remains intact in the intestine and will be fermented by good beneficial bacteria such as Bifidobacteria and Lactobacilli. That makes resistant starch a potential prebiotic (Haralampu, 2000). Nipah, which has a high starch content, has not been utilized to the maximum. Therefore, the writing of this review will discuss the potential of Nipah resistant starch in diabetes and the modulation of microflora body norms.

\section{Methods}

This review writing procedure is done by searching various literature electronically by accessing International and National article searches and books through databases such as Google Scholar, ScienceDirect, and others using keywords related to the discussion of resistant starch, diabetes mellitus, and microflora in the intestine. Titles and abstracts are selected and classified based on the needs of writing reviews. The articles used were selected for 20102020. Selected articles are then saved to Mendeley according to specific sub-chapters. The next step is to synthesize articles that are relevant to the topic in a narrative manner. Both the equation and the difference from the data that has been collected will be discussed to conclude (interpretation). The understanding is chronologically arranged into a particular theme or subchapter, then made into a framework of writing and then developed to become a complete review writing. As many as 70 sources are 66 international and 4 National, consisting of 61 research journals, three review journals and three books.

\section{Discussion}

\section{Resistant Starch}

Starch is the most common type of carbohydrate found in various kinds of food and is widely consumed because it has a role as the primary source of energy for human needs, where almost $60-70 \%$ of the total energy needed by humans comes from carbohydrates (starch) (Sari, 2018). Starch is a glucose homopolymer with an $\alpha$-glycosidic bond (Sutrisno, 2015). Polysaccharides used as a source of nutrients (e.g., starch, dextrin, glycogen, and cellulose) are a combination of glucose units, differing only in their type of interrelationship. Polysaccharides as a group contain 
monosaccharides other than glucose, both alone and combined (Alcázar-Alay \& Meireles, 2015). Starch comes as a grain, size and shapes depending on the origin of the plant (Zhu et al., 2020). Starch is increasingly being used in various industrial applications, especially in the food industry and renewable energy sources. The application of starch in the food industry is due to its nutritional value, which acts as a major energy source (Delcour \& Hoseney, 2010), and its increasingly broad technological function. Amylose and amylopectin polymers, lipids, proteins and phosphorus present in starch granules have a significant effect on the physicochemical properties and function of starches, so starch can be modified to increase its benefits and eliminate deficiencies in its original characteristics (Alcázar-Alay \& Meireles, 2015), where the starch modification results in the form of resistant starch.

Prebiotics are indigestible food ingredients that will stimulate the growth and activity of bacteria in the colon, especially those that can improve the health of food Ingredients foods that have prebiotic properties are raffinose, inulin, oligosaccharide fructose (FOS), galactose lactose, lactolusa and RS (Masrukan, 2020). FAO/WHO defines probiotics as live microorganisms that provide health benefits to the host (FAO/WHO., c2001). 9 Lactic acid bacteria (BAL) and bifidobacteria are the most common types of microbes used as probiotics (Tabuchi et al., 2003).

Resistant starch is a component of complex carbohydrates and prebiotics that is relatively resistant to gastric acid hydrolysis and cannot be digested in the small intestine by the enzyme $\alpha$-amylase produced by the pancreatic gland (Microbiome et al., 2017; Setiarto et al., 2018). However, the resistant starch will be fermented by probiotic bacteria in the large intestine that produces products in the form of short-chain fatty acids (SCFAs) (Shen et al., 2009; Chen et al., 2010; Maki et al., 2012; Belobrajdic et al., 2012; Araújo et al., 2016). Resistant starch is a type of dietary fibre that, in addition to increased glucose metabolism, also has an effect that can be modulated by essential insulin sensitivity (Gower et al., 2016). Resistant starch can be found in all foodstuffs that contain starch, but some factors affect the amount of starch in food in the amount and type of starch at the beginning, processing, cooking, storage, and how to consume it (Sari, 2018). This is the difference between the amount of starch undergoing complex activity of amylolytic enzymes and the amount of glucose (as the starch equivalent) produced due to hydrolysis with the enzyme (Leszczynski \& Technology, 2004).

Resistant starch can be classified into several subtypes depending on the plant source and its processing:

RS1: starch granules trapped in plant materials with entire and physically indigestible cell walls sourced from grains and partial milled seeds and legumes or lentils. This type of starch is not available for amylolytic enzymes because the digestive tract lacks enzymes capable of degrading cellulose, hemicellulose, lignin, and other elements of the plant cell wall so that the starch along with fragments of plant tissue pass through the small intestine in its intact form;

RS2: granules of native (raw) resistant starch such as those found in bananas, raw potatoes or high amylose corn, wheat, and others. RS2 of all these foods showed similar resistance to enzymatic activity (Leszczynski \& Technology, 2004; Chen et al., 2010; Robertson, 2012; Jyothsna \& Hymavathi, 2017).

Resistant starch type 3 is a substance deposited from a paste or starch gel in the process of retrogradation. During gelatinization, starch is partially polymerized due to lower temperature interactions (at $<1.5 \%$ amylose or $>10 \%$ amylopectin). Water moves the swollen granules into the solution to produce a colloidal aqueous solution (starch paste). Starch paste results from retrogradation in a thermostable structure formed by amylose rather than by amylopectin. The number of resistant starches produced in this way is increasing along with the increasing content of amylose in starch; RS4, chemically or physically modified starch (especially by thermal treatment), or by both treatments, usually through esterification, cross-bonding or translation (Leszczynski \& Technology, 2004; Chen et al., 2010; Robertson, 2012; Jyothsna \& Hymavathi, 2017). RS5 is a starch formed when interacting with lipid compounds, resulting in amylose forming a single helix complex with fatty acids and fatty alcohols. Furthermore, linear starch chains formed in helical structures will also form complexes with fatty acids in the helical cavity. Starches will bind to each other and are difficult to hydrolyze by amylase enzymes. The formation of the lipid amylose complex is an instant reaction, and the complex can be formed after the cooking process, so RS5 is considered stable to heating (Birt et al., 2013).

\section{Resistant Starch Origin of Nipah as a Modern Functional Food}

Resistant starch cannot be digested in the small intestine but can be used in low-fat and sugar formulations (Garg et al., 2017). Resistant starch has properties similar to fibre, i.e. non-viscous dietary fibre, and shows physiological benefits or promising postprandial effects on appetite regulation and body metabolism that can result in disease prevention (Bodinham, Frost, \& Robertson, 2010; Garg et al., 2017). The prevalence of food, as the statement, is known as a functional food (Fuentes-Zaragoza et al., 2010). As for food that can be said to be practical, if it has a good taste and contains components (both nutritional and non-nutrient) that provide benefits, there are organ functions in the body and can maintain health or have beneficial physiological effects (Ashwar et al., 2016). 


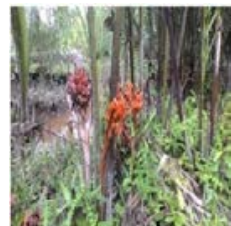

(a)

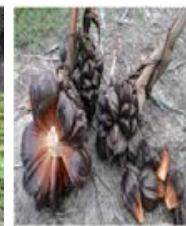

(b)

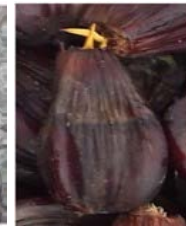

(c)

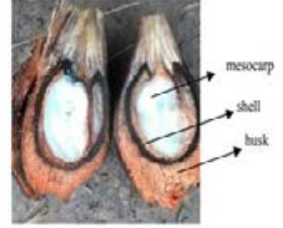

(d)
Figure 1. Nipah and fruit (a), bunches of ripe Nipah fruit (b), Nipah fruit buds (c), a cross-section of Nipah (d)

The study of Ulyarti et al. (2017) shows the comparison of the proximal components of Nipah flour based on the level of freshness and processing of Nipah fruit (Table 1).

Table 1. Chemical composition of some types of Nipah flour (Ulyarti et al., 2017).

\begin{tabular}{lcccc}
\hline Compone & \multicolumn{4}{c}{ Type of Flour } \\
\cline { 2 - 5 } \multicolumn{1}{c}{ nt (\%) } & A & B & C & D \\
\hline Water & $7.79 \pm 0.22$ & $7.01 \pm 0.42$ & $7.30 \pm 0.02$ & $5.64 \pm 0.00$ \\
Ash & $2.72 \pm 0.36$ & $1.26 \pm 0.28$ & $2.52 \pm 0.01$ & $3.34 \pm 0.01$ \\
Protein & $2.66 \pm 1.73$ & $2.90 \pm 1.36$ & $5.98 \pm 0.01$ & $8.17 \pm 0.04$ \\
Fat & $12.25 \pm 2.13$ & $11.95 \pm 2.07$ & $1.45 \pm 0.01$ & $1.46 \pm 0.00$ \\
Coarse & $0.18 \pm 0.05$ & $0.31 \pm 0.11$ & $17.68 \pm 0.05$ & - \\
$\begin{array}{l}\text { Fiber } \\
\text { Carbohyd }\end{array}$ & 74.57 & 76.88 & 82.75 & 81.39 \\
$\begin{array}{l}\text { rates } \\
\text { Starch }\end{array}$ & $39.05 \pm 6.72$ & $37.58 \pm 5.93$ & $32.73 \pm 0.05$ & $35.66 \pm 0.08$
\end{tabular}

Description: Flour A from Nypa fruit that has germinated; Flour B from the fallen fruit of Nypa; Flour C from fresh Nypa fruit; and Flour D from Flour extracted 100 Mesh

In Table 1, it is seen that sprouted Nipah fruit can still be processed into flour with a starch content of 39\%. Flour from fresh Nipah fruit has the lowest fat content. The fat content of flour increases along with the decrease in the freshness of the fruit. In addition to its low-fat content, flour from fresh Nipah fruit also has a very high range of coarse fibre (17.68\%). This allows Nipah flour as a raw material in low-calorie food processing. In addition, the extraction of starch with 100 mesh sying can increase the starch level from $32.73 \%$ to $35.66 \%$. The high total starch of Nipah fruit indicates that this starch of origin of Nipah has the potential as a source of resistant starch (Ulyarti et al., 2017).

\section{Role of Nipah Resistant Starch as Prebiotic}

Microflora in the large intestine is highly dependent on the presence of food. Resistant starch is one of the highest food sources of carbohydrate content, where this starch is not digested in the small intestine by digestive enzymes but will be fermented in the large intestine. This shows that resistant starch acts as a prebiotic that serves as a food source for intestinal microflora. The results of resistant starch fermentation by colon bacteria are short-chain fatty acids (SCFAs), primarily acetate, propionate, and butyrate (Garg et al., 2017), as well as other end products that lower local pH, stimulating musin (Krumbeck et al., 2016). SCFA promotes colon blood flow and absorption of fluids and electrolytes (Garg et al., 2017). Resistant starch has various beneficial effects that positively affect digestive tract function, microbial flora, blood cholesterol levels, glycemic index and aid diabetes control (Garg et al., 2017; Division, 2018; Rengadu et al., 2020).

Prebiotics are foodstuffs with oligosaccharides that cannot be digested by the host but provide beneficial effects by stimulating the growth of digestive tract microflora (Widanarni, Jeanni, I.N., 2014) by modulating the microbiota in the large intestine (Ferreira et al., 2011). Prebiotics has a defined advantage by enriching organisms already present in the intestinal ecosystem (the original members). Fermentation of prebiotic carbohydrates produces butyric and other short-chain fatty acids (SCFAs) and other end products that lower local $\mathrm{pH}$, stimulating musin (Krumbeck et al., 2016).

The high total starch of Nipah fruit indicates that this starch of origin of Nipah has the potential as a source of resistant starch (Ulyarti et al., 2017) which can become a new prebiotic to overcome unbalanced microbiota due to improper diet, radiotherapy, antibiotic treatment, stress situations and others. Consumption of certain probiotics and prebiotics effectively improves body health (Ferreira et al., 2011). Research shows that consumption of high-fat diet foods (HFD) can increase the population of commensal gut bacteria living in adipose tissue and blood, referred to as translocations of gut bacteria. The impact of these translocations causes imbalances in glucose metabolism and weight loss. The increased translocation of bacteria from gram-negative bacteria into adipose tissue is mainly responsible for the continuous refuelling of inflammatory antigens that characterize the origin of low-level inflammation as the onset of diabetes and obesity resulting in the need for treatment of metabolic diseases using probiotic strategies (Klopp et al., 2011). Probiotic, prebiotic and synbiotic foods in gut microecology, supplements and feed ingredients are abundant on the market. Although confirmation of their benefits and mechanisms of action is still highly suspected, yet they remain necessary tools to help maintain and reduce various diseases that interfere with human and animal health (Ferreira et al., 2011).

\section{Intestinal Microflora and Type 2 Diabetes}

Diabetes mellitus is an epidemic or outbreak of disease that has spread in various parts of the world as a group of endocrine disorders and heterogeneous metabolism followed by disruptions in carbohydrate, fat and protein metabolism, both larger and smaller and characterized by the presence of chronic hyperglycemia which is also associated with high cardiovascular risk (CVD) (Wang et al., 2016; Susanto et al., 2018; Costa et al., 2019). Type 2 diabetes (DM 2) itself is believed to be caused by a series of double risk factors such as genetic liability, age, weight or obesity, and the unhealthy lifestyle of a person (Han \& Lin 
2014), for example, by consuming high-fat foods. This will alter the gut microbiota so that there is a decrease in the number of good bacteria along with an increase in the number of harmful bacteria that result in a state of metabolic endotoxemia that triggers an inflammatory response and plays a role in the development of diabetes (Abo et al., 2013). Studies have shown that various chronic diseases in humans are influenced by intestinal microecological disorders (Bajzer \& Seeley, 2006; Zhang et al., 2010; Qin et al., 2012; Cox \& Sohn, 2014; Cox \& Blaser, 2015; Yono et al., 2015; Manrique et al., 2016). Intestinal flora is very important in environmental factors, and its changes are associated with a series of metabolic diseases such as diabetes (Qin et al., 2012).

Type 2 diabetes mellitus is a metabolic disorder that usually occurs due to excess calorie intake (sugar) that is unbalanced with energy expenditure. Therefore, people with diabetes need foods low in sugar and do not raise blood sugar levels drastically (Susanto et al., 2018). Microbes in the gut play a significant role in extracting energy from food through various enzymatic activities. Microflora in the small intestine (host) exhibit a complex ecosystem and affect host physiology through multiple mechanisms (Widiastini et al., 2018).

The growing research in animals, especially mice, provides evidence by showing the presence of dysbiosis related to the contribution of gut microbes to the onset of low levels of inflammation that characterized early metabolic disorders such as obesity and type 2 diabetes that is associated with endotoxemia and inflammation through mechanisms related to dysfunction of intestinal barrier disorders that can increase the absorption of bacterial parent compounds (for example, lipopolysaccharides (LPS) which are toxins from Gramnegative bacteria) and depletion of beneficial bacteria that produce SCFAs (Zhang \& Zhang, 2013; Sabatino et al., 2017). The microbiota also contributes to the further development of DM 2 through its inflammatory component, which has been extended to various DM-related complications, including diabetic retinopathy, kidney toxicity, atherosclerosis, hypertension, diabetic foot ulcers, cystic fibrosis and Alzheimer's disease (Zhang \& Zhang 2013).

The host cannot digest some plant polysaccharides and complex carbohydrates; However, the presence of fermentation in the large intestine makes the colon microbial community successful in converting food substances in the form of resistant starch (RS) into monosaccharides and short-chain fatty acids (SCFAs) that support the development of beneficial microorganisms and harm harmful microorganisms/other pathogens and can regulate lipid metabolism and feelings of fullness (Zhang et al., 2015; Ojeda et al., 2016; Armas Ramos et al., 2019). Any modification of the gut microbiome will affect the health and metabolic status of the host, where the host and microbiome are interconnected in infinite symbiosis in the intestine (Slawinska et al., 2019). SCFAs are agonists for free fatty acid receptors 2, 3 (FFAR2 and FFAR3, respectively) and $2 \mathrm{G}$ protein paired receptors in the digestive tract expressed in enteroendocrine cells in the intestinal epithelium (Haenen et al., 2013). SCFA can increase the expression of such functional proteins in the gut due to its ability to mediate the release of glucagon-likepeptide 2 (Ble-Castillo et al., 2010). Therefore, maintaining an excellent symbiotic relationship between the human body and intestinal microorganisms is essential for human health (Zhao, 2013).

\section{Modulation of Intestinal Microflora with Resistant Starch Intervention in Treatment of Type 2 Diabetes Patients}

The human body stores many microbiotas that act as probiotics and form a stable symbiotic relationship with the host. The microbiota is needed to maintain the health of the human body (Wang et al., 2018). Consumption or application of resistant starch as a source of prebiotics provides health benefits to the host associated with modulation of the microbiota in the colon (Ferreira et al., 2011), whereby consuming fermentable fibres (prebiotics) or consumption of combinations of their prebiotics can enrich larger and more diverse populations of gut microbes (Krumbeck et al., 2016).

Consumption of resistant starch in healthy adults of 15$60 \mathrm{~g} /$ day leads to increased glycemia, insulin sensitivity, and satiety, as well as decreased energy consumption (Maziarz, 2013) due to the rise and decrease in postprandial glucose levels mediated by the insulin response, in which large amounts of endogenous insulin are released, usually within 10 minutes in response to nutrient intake (Lin et al., 2015). Resistant starch is well tolerated up to $45 \mathrm{~g} /$ day and can be consumed with minimal digestive effects (Maziarz, 2013). Research shows that rs consumption can modulate the composition of the microbiota, SCFA concentration, and host gene expression in the pig's intestines (Haenen et al., 2013). Native banana starch (NBS) also has the potential to be used as resistant starch that acts as a prebiotic whereby consuming the starch as much as $24 \mathrm{~g}$ / day for four weeks can lose weight and improve insulin sensitivity in the group of people with type 2 diabetes (Ble-Castillo et al., 2010).

The addition of $\mathrm{RS}$ to the rations has the potential to modulate the composition of the microbiota, SCFA concentration, and host gene expression in the gut to improve gut health and host function by altering the community or structure of the gut microbiota and increasing SCFA production (Haenen et al., 2013; Zhou et al., 2020). RS is thought to mediate most of its health benefits, including increased satiety through SCFA action. 
SCFA and as butyrate can cause beneficial metabolic effects through increased mitochondrial activity. The primary substrate is used as an energy source for colonocytes epithelial cells, preventing metabolic endotoxemia, intestinal gluconeogenesis activity, and inhibiting malignant cell transformation through various routes of gene expression and hormone regulation (Hartstra et al., 2015; Ojeda et al., 2016; Garg et al., 2017).

SCFA induces the production and secretion of endogenous gut hormones, including glucagon-like peptide 1 (GLP-1) and peptide YY (PYY). Elevated glucagon-like GLP-1 regulates insulin and glucagon secretion via GLP-1 receptors on pancreatic cells. (Belobrajdic et al., 2012; Bindels et al., 2017). PYY and GLP-1 signals associated with rs use in food can alter long-term energy balance through interaction with neural pathways in the brain (Keenan et al., 2006). Animal studies show that the proportion of microbiota such as Bifidobacterium and Akkermansia is positively correlated with mouse feeding response, intestinal weight, proglucagon expression levels, precursors of the anti-obesity hormone or diabetic GLP-1 gut (Tachon et al., 2013).

Research related to the composition of the gut microbiota group in people suffering from type 2 diabetes mellitus and in regular or healthy people showed that in people with DM 2 there was no significant difference in the bacterial genera Prevotella and Fusobacterium. Still, the concentration of Lactobacillus and Bifidobacterium bacteria in faecal samples showed a noticeable difference in DM 2 patients and healthy individuals. This proves that the onset of DM 2 disease is closely related to changes in the composition of gut microbial flora (Sedighi et al., 2017), where intestinal microflora plays an important role in the nutritional status and health of the host through modulation of immune function and metabolism (Oršolić et al., 2017). Recent evidence also suggests that the continuous accumulation of intestinal microflora will play a role as a potential new contributor in the pathogenesis or cause of DM disease (Leszczynski \& Technology, 2004).

Consumption of resistant starch (RS) has been shown to be beneficial in affecting insulin sensitivity in healthy individuals and those with metabolic syndrome (Bodinham et al., 2014), although the exact composition and/or metabolic activity of the gut microbial community that contributes to the onset of obesity and type 2 diabetes in humans is still not known (Everard \& Cani, 2013) Bodinham et al., 2014). But recent studies have shown the beneficial metabolic effects of RS3 on DM 2 from treatment with resistant starches that act as prebiotics that can lower blood glucose levels, improve dyslipidemia, reduce insulin resistance, and improve insulin sensitivity.

\section{Conclusion}

Resistant starch is a component of carbohydrates that cannot be digested in the small intestine by enzymes $\alpha$ amylase and has many health benefits. It has the potential as a functional food. Nipah fruit has a high enough starch content to be a source of resistant starch. In the small intestine, resistant starch is not absorbed to remain intact. This starch has a high enough starch content in the large intestine to be a source of resistant starch. In the small intestine, resistant starch is not absorbed to remain intact.

\section{Acknowledgement}

We thank the Ministry of Education and Culture (Kemendikbud) in 2020 for a grant to write this review.

\section{Declaration statement}

The authors reported no potential conflict of interest.

\section{References}

Abo, F. H., Ashour, Z. A., Shahin, R. Y., Ragab, S. B., \& Attia, M. Y. (2013). Role of intestinal microflora ( Lactobacillus Acidophilus ) in the phagocytic function of leukocytes in type 2 diabetic patients. Egyptian Journal of Medical Human Genetics, 14(1), 95-101. https://doi.org/10.1016/j.ejmhg.2012.10.003

Alcázar-Alay, S. C., \& Meireles, M. A. A. (2015). Physicochemical properties, modifications and applications of starches from different botanical sources. Food Science and Technology, 35(2), 215-236. https://doi.org/10.1590/1678-457X.6749

American Diabetes Association. (2013). Standards of Medical Care in Diabetes-2013. Diabetes Care 36, S11-S66. https://doi.org/10.2337/dc13-S011

Araújo, M. De, Carine, G., José, A., Marlon, É., Flores, M., Smanioto, J., Queiroz, L., Jacob-lopes, E., Raimundo, C., Grosso, F., Ragagnin, C., \& Menezes, D. (2016). Effect of resistant starch (Hi-maise) on the survival of Lactobacillus acidophilus microencapsulated with sodium alginate. Journal of Functional Foods, 21, 321329. https://doi.org/10.1016/j.jff.2015.12.025

Armas Ramos, R., Martínez García, D., \& Pérez Cruz, E. (2019). Fructanos tipo inulina: efecto en la microbiota intestinal, la obesidad y la saciedad. Gaceta Médica Espirituana, 21(2), 134-145.

Ashwar, B. A., Gani, A., Shah, A., Wani, I. A., \& Masoodi, F. A. (2016). Preparation, health benefits and applications of resistant starch - a review. 287-301. https://doi.org/10.1002/star.201500064

Bajzer, M., \& Seeley, R. J. (2006). Physiology: obesity and gut flora. Nature, 444(7122), 1009-1010.

Belobrajdic, D. P., King, R. A., Christophersen, C. T., \& Bird, A. R. (2012). Dietary resistant starch dosedependently reduces adiposity in obesity-prone and obesity-resistant male rats. Nutrition \& Metabolism, 


\section{9(1), 1. https://doi.org/10.1186/1743-7075-9-93}

Bimo Setiarto, R. H., Widhyastuti, N., \& Setiadi, D. (2018). Improvement Resistant Starch from Modified Sorghum Flour by Using Fermentation and Autoclaving-Cooling Cycling. Jurnal Ilmu Pertanian Indonesia, 23(1), 10-20. https://doi.org/10.18343/jipi.23.1.10

Bindels, L. B., Munoz, R. R. S., Gomes-neto, J. C., Mutemberezi, V., Martínez, I., Salazar, N., Cody, E. A., Quintero-villegas, M. I., Kittana, H., Reyes-gavilán, C. G. D. L., Schmaltz, R. J., Muccioli, G. G., Walter, J., \& Ramertait, A. E. (2017). Resistant starch can improve insulin sensitivity independently of the gut microbiota. Microbiome, 1-16. https://doi.org/10.1186/s40168017-0230-5

Birt, D. F., Boylston, T., Hendrich, S., Jane, J., Hollis, J., Li, L., Mcclelland, J., Moore, S., Phillips, G. J., Rowling, M., Schalinske, K., Scott, M. P., \& Whitley, E. M. (2013). Resistant Starch : Promise for Improving Human Health 1 2. 587-601. https://doi.org/10.3945/an.113.004325.TABLE

Ble-Castillo, J. L., Aparicio-Trapala, M. A., Francisco-Luria, M. U., Cordova-Uscanga, R., Rodriguez-Hernandez, A., Mendez, J. D., \& Diaz-Zagoya, J. C. (2010). Effects of native banana starch supplementation on body weight and insulin sensitivity in obese type 2 diabetics. International Journal of Environmental Research and Public Health, 7(5), 1953-1962. https://doi.org/10.3390/ijerph7051953

Bodinham, C L, Smith, L., Thomas, E. L., Bell, J. D., Swann, J. R., Costabile, A., Russell-Jones, D., Umpleby, A. M., \& Robertson, M. D. (2014). Efficacy of increased resistant starch consumption in human type 2 diabetes. Endocrine Connections, 3(2), 75-84. https://doi.org/10.1530/ec-14-0036

Bodinham, Caroline L, Frost, G. S., \& Robertson, M. D. (2010). Acute ingestion of resistant starch reduces food intake in healthy adults British Journal of Nutrition. 917-922.

https://doi.org/10.1017/S0007114509992534

Chen, L., Liu, R., Qin, C., Mph, Y. M., \& Zhang, J. (2010). Short Communication Sources and intake of resistant starch in the Chinese diet. 19(February), 274-282.

Costa, E. S., França, C. N., Fonseca, F. A. H., Kato, J. T., Bianco, H. T., Freitas, T. T., Fonseca, H. A. R., Figueiredo Neto, A. M., \& Izar, M. C. (2019). Beneficial effects of green banana biomass consumption in patients with prediabetes and type 2 diabetes: A randomized controlled trial. British Journal of Nutrition, 121(12), 1365-1375. https://doi.org/10.1017/S0007114519000576

Cox, L. M., \& Blaser, M. . (2015). Antibiotics in early life and obesity. Nat. Rev. Endocrinol, 11(3), 182-190.

Cox, L. M., \& Sohn, J. (2014). Altering the intestinal microbiota during a critical developmental window has lasting metabolic consequences. Cell, 158(4), 705-
721.

Delcour, J. A., \& Hoseney, R. C. (2010). Principles of Cereal Science and Technology. In 3rd edn. AACC International, Inc.

Division, M. (2018). Effect of lactic acid bacteria fermentation and autoclaving-cooling for resistant starch and prebiotic properties of modified taro flour. 25(August), 1691-1697.

Everard, A., \& Cani, P. D. (2013). Diabetes, obesity and gut microbiota. Best Practice and Research: Clinical Gastroenterology, 27(1), 73-83. https://doi.org/10.1016/j.bpg.2013.03.007

Ferreira, C., Salminen, S., Lukasz, G., Brizuela, M., Sanchez, L., Carneiro, H., \& Bonnet, M. (2011). Terminology Concepts of Probiotic and Prebiotic and Their Role in Human and Animal Health. Revista de Salud Animal, 33(3), 137-146.

Fuentes-Zaragoza, M.J. Riquelme-Navarrete, E. SánchezZapata, J. A. P.-Á. *. (2010). Resistant starch as functional ingredient: A review. Food Research International.

https://doi.org/10.1016/j.foodres.2010.02.004

Garg, N. K., Singh, A., \& Biokimia, D. (2017). Jurnal Internasional Mikrobiologi Terkini dan Ilmu Terapan. 6, 2046-2057.

Gower, B. A., Bergman, R., Stefanovski, D., Darnell, B., Ovalle, F., Fisher, G., Sweatt, S. K., Resuehr, H. S., \& Pelkman, C. (2016). Baseline insulin sensitivity affects response to high-amylose maize resistant starch in women: a randomized, controlled trial. Nutrition \& Metabolism, 13(2), 1-8. https://doi.org/10.1186/s12986-0160062-5

Haenen, D., Zhang, J., da Silva, C. S., Bosch, G., van der Meer, I. M., van Arkel, J., van den Borne, J. J. G. C., Gutiérrez, O. P., Smidt, H., Kemp, B., Müller, M., \& Hooiveld, G. E.

Han, J. L., \& Lin, H. L. (2014). Intestinal microbiota and type 2 diabetes: From mechanism insights to therapeutic perspective. World Journal of Gastroenterology, 20(47), 17737-17745.

https://doi.org/10.3748/wjg.v20.i47.17737

Haralampu, S. G. (2000). Resistant Starch - Review of The Physical Properties and Biological Impact of RS. J. Carbohydrate. Polym, 41, 285-292.

Hartstra, A. V., Bouter, K. E. C., Bäckhed, F., \& Nieuwdorp, M. (2015). Insights into the role of the microbiome in obesity and type 2 diabetes. Diabetes Care, 38(1), 159165. https://doi.org/10.2337/dc14-0769

Johnson, I. T., \& Southgate, D. A. T. (1994). An Introduction to the Dietary Fibre Hypothesis. In: Dietary Fibre and Related Substances. In Food Safety Series. Springer.

Jyothsna, E., \& Hymavathi, T. V. (2017). Resistant starch: Importance, categories, food sources and physiological effects. Journal of Pharmacognosy and Phytochem, 6(2), 
67-69.

Keenan, M. J., Zhou, J., Mccutcheon, K. L., Raggio, A. M., Bateman, H. G., Todd, E., Jones, C. K., Tulley, R. T., Melton, S., Martin, R. J., Hegsted, M., Michael, J., Zhou, J. U. N., Kathleen, L., Raggio, A. M., Gale, H., Todd, E., Jones, C. K., Tulley, R. T., ... Hegsted, M. (2006). Effects of Resistant Starch , A Non-digestible Fermentable Fiber , on Reducing Body Fat.

Kim, B. S., Kim, H. S., Hong, J. S., Huber, K. C., Shim, J. H., \& Yoo, S. H. (2013). Effects of amylosucrase treatment on molecular structure and digestion resistance of pregelatinized rice and barley starches. Food Chem, 138, 966-975.

https://doi.org/10.1016/j.foodchem.2012.11.028.

Klopp, P., Vachoux, C., Amar, J., Chabo, C., Bermu, L. G., Lahtinen, S., Ouwehand, A., Langella, P., \& Rautonen, N. (2011). Intestinal mucosal adherence and translocation of commensal bacteria at the early onset of type 2 diabetes: molecular mechanisms and probiotic treatment. 3, 559-572. https://doi.org/10.1002/emmm.201100159

Krumbeck, J. A., Maldonado-gomez, M. X., Ramer-tait, A. E., Hutkins, R. W., Ramer-tait, A. E., \& Hutkins, R. W. (2016). Prebiotics and synbiotics: Dietary strategies for improving gut health Prebiotics and synbiotics : Dietary strategies for improving gut health. 32, 110-119. https://doi.org/10.1097/MOG.0000000000000249

Lau, Harper, W., A. Hanna, V., Woo, K. G., Dawson, J., François, L., MacCallum, M., Clement, S., Simpson, \& Hopkins. (2008). Pharmacologic Management of Type 2 Diabetes. Canadian Journal of Diabetes, 32, 158-162.

Leszczynski, W. (Wroclaw A. U. (Poland) D. of F. S., \& Technology). (2004). Resistant starch - classification, structure, production. Polish Journal of Food and Nutrition Sciences (Poland), 13, 37-50.

Lin, C. H., Chang, D. M., Wu, D. J., Peng, H. Y., \& Chuang, L. M. (2015). Assessment of blood glucose regulation and safety of resistant starch formula-based diet in healthy normal and subjects with type 2 diabetes. Medicine (United States), 94(33), e1332. https://doi.org/10.1097/MD.0000000000001332

Maki, K. C., Pelkman, C. L., Finocchiaro, E. T., Kelley, K. M., Lawless, A. L., Schild, A. L., \& Rains, T. M. (2012). Resistant Starch from High-Amylose Maize Increases Insulin Sensitivity in Overweight and Obese Men 1 - 3. 14. https://doi.org/10.3945/jn.111.152975.resistance

Manrique, P., Bolduc, B., \& Walk, S. T. (2016). Healthy human gut phageome, U.S.A. Proc. Natl. Acad. Sci., 113(37), 10400-10405.

Masrukan. (2020). Potensi Modifikasi Pati Dengan Esterifikasi Sebagai Prebiotik. J. Agrotech., 1(1), 1-14.

Maziarz, M. P. (2013). Role of fructans and resistant starch in diabetes care. Diabetes Spectrum, 26(1), 35-39. https://doi.org/10.2337/diaspect.26.1.35
Microbiome, G., Brislawn, C. J., Bernhardt, J., Lamendella, R., Mcdermott, J. E., Ackermann, G., Knight, R., Riedel, K., Krauss, R. M., Schmitt-kopplin, P., \& Jansson, K. (2017). crossm Impact of Dietary Resistant Starch on. 8(5), 116.

Nasrin, T. A. A., \& Anal, A. K. (2014). Resistant starch III from culled banana and its functional properties in fish oil emulsion. Food Hydrocolloid, 35, 403-409. https://doi.org/10.1016/j.foodhyd.2013.06.019

Ojeda, P., Bobe, A., Dolan, K., Leone, V., \& Martinez, K. (2016). Nutritional modulation of gut microbiota - the impact on metabolic disease pathophysiology. Journal of Nutritional Biochemistry, 28(March 2018), 191-200. https://doi.org/10.1016/j.jnutbio.2015.08.013

Onyango, C., Bley, T., Jacob, A., Henle, T., \& Rohm, T. (2006). Influence of incubation temperature and time on resistant starch type III formation from autoclaved and acid-hydrolyzed cassava starch. Carbohyd Polym, 66 , 494-499.

https://doi.org/10.1016/j.carbpol.2006.04.002

Oršolić, N., Jembrek, M. J., \& Terzić, S. (2017). Honey and quercetin reduce ochratoxin A-induced DNA damage in the liver and the kidney through the modulation of intestinal microflora. Food and Agricultural Immunology, 28(5), 812-833. https://doi.org/10.1080/09540105.2017.1313819

Ozturk, S., Koksel, H., \& Kahraman, K. (2011). Production of resistant starch from acid- modified amylotype starches with enhanced functional properties. J Food Eng, 103, 156-164. https://doi.org/10.1016/j.jfoodeng.2010.10.011.

Qin, J., Li, Y., \& Cai, Z. (2012). A metagenome-wide association study of gut microbiota in type 2 diabetes. Nature, 490(7418), 55-60.

Rengadu, D., Gerrano, A. S., \& Mellem, J. J. (2020). Original article Prebiotic effect of resistant starch from Vigna unguiculata ( L .) Walp . ( cowpea) using an in vitro simulated digestion model. 332-339. https://doi.org/10.1111/ijfs.14304

Robertson, M. D. (2012). Dietary-resistant starch and glucose metabolism. Current Opinion in Clinical Nutrition and Metabolic Care, 15(4), 362-367. https://doi.org/10.1097/MC0.0b013e3283536931

Sabatino, A., Regolisti, G., Cosola, C., Gesualdo, L., \& Fiaccadori, E. (2017). Intestinal Microbiota in Type 2 Diabetes and Chronic Kidney Disease. Current Diabetes Reports, 17(3). https://doi.org/10.1007/s11892-0170841-Z

Sahoo, G., Mulla, N. S. S., Ansari, Z. A., \& Mohandas, C. (2012). Antibacterial activity of mangrove leaf extracts against human pathogent. Indian J. Pharm. Sci., 74(4), 349.

Sandberg, J. C., Björck, I. M. E., \& Nilsson, A. C. (2017). Effects of whole grain rye, with and without resistant 
starch type 2 supplementation, on glucose tolerance, gut hormones, inflammation and appetite regulation in an 11 - 14. 5 hour perspective; a randomized controlled study in healthy subjects. 1-11. https://doi.org/10.1186/s12937-017-0246-5

Sari, D. K. (2018). Pati Tahan Cerna untuk Pencegahan Diabetes Tipe-2. Pustaka Unpad.Ac.Id Program Studi Ilmu Kesehatan Masyarakat Program Pascasarjana Fkultas Kedokteran Universitas Padjajaran, Bandung, Indonesia, 1-11.

Sedighi, M., Razavi, S., Navab-Moghadam, F., Khamseh, M. E., Alaei-Shahmiri, F., Mehrtash, A., \& Amirmozafari, N. (2017). Comparison of gut microbiota in adult patients with type 2 diabetes and healthy individuals. Microbial Pathogenesis, 111(September), 362-369. https://doi.org/10.1016/j.micpath.2017.08.038

Shen, L., Keenan, M. J., Martin, R. J., Tulley, R. T., Raggio, A. M., Mccutcheon, K. L., \& Zhou, J. (2009). Dietary Resistant Starch Increases Hypothalamic POMC Expression in Rats. 17(1), 40-45. https://doi.org/10.1038/oby.2008.483

Shi, M. M., \& Gao, Q. Y. (2011). Physicochemical properties, structure and in vitro digestion of resistant starch from waxy rice starch. Carbohyd Polyme, 84, 11511157. https://doi.org/10.1016/j. carbpol.2011.01.004.

Slawinska, A., Dunislawska, A., Plowiec, A., Radomska, M., Lachmanska, J., Siwek, M., Tavaniello, S., \& Maiorano, G. (2019). Modulation of microbial communities and mucosal gene expression in chicken intestines after galactooligosaccharides delivery In Ovo. PLOS ONE, 14(2),

https://doi.org/10.1371/journal.pone.0212318

Susanto, E. T., Rejeki, S., Pertanian, F., \& Oleo, U. H. (2018). Pengaruh Penambahan Minyak Sawit Dalam Proses Penanakan Nasi Pada Rice Cooker Terhadap Pembentukan Pati Resisten 5 Untuk Penderita Diabetes Melitus ( Dm ) Tipe 2. J. Sains Dan Teknologi Pangan (JSTP), 3(4), 1460-1469.

Sutrisno, A. R. (2015). Karakteristik Sirup Glukosa Dari Tepung Ubi Ungu ( Kajian Suhu Likuifikasi Dan Konsentrasi A -Amilase ): Kajian Pustaka Glucose Syrup Characteristic from Sweet Potato Flour ( Study on Liquefaction Temperature and Enzyme Concentration ): A Review. Jurnal Pangan Dan Agroindustri, 3(4), 1531-1537.

Tabuchi, M., Ozaki, M., Tamura, A., Yamada, N., Ishida, T., Hosoda, M., \& Hosono, A. (2003). Antidiabetic effect of Lactobacillus GG in streptozotocin-induced diabetic rats. Biosci Biotechnol Biochem., 67, 1421-1424.

Tachon, S., Zhou, J., Keenan, M., Martin, R., \& Marco, M. L. (2013). responses. 83, 299-309. https://doi.org/10.1111/j.1574-6941.2012.01475.x

Ulyarti, Nazarudin, \& Sari, D. W. (2017). The study of functional properties of Nypa fruticans flour. AIP Conference Proceedings, 1823(March). https://doi.org/10.1063/1.4978100

Wang, C., Yin, Y., Cao, X., \& Li, X. (2016). Effects of Maydis stigma polysaccharide on the intestinal microflora in type-2 diabetes. Pharmaceutical Biology, 54(12), 3086-3092.

https://doi.org/10.1080/13880209.2016.1211153

Wang, J., Zheng, J., Shi, W., Du, N., Xu, X., Zhang, Y., Ji, P., Zhang, F., Jia, Z., Wang, Y., Zheng, Z., Zhang, H., \& Zhao, F. (2018). Dysbiosis of maternal and neonatal microbiota associated with gestational diabetes mellitus. Gut, 67(9), 1614-1625. https://doi.org/10.1136/gutjnl-2018-315988

Widanarni, Jeanni , I.N., \& S. (2014). Prebiotik, probiotik, dan sinbiotik untuk mengendalikan koinfeksi Vibrio harveyi dan IMNV pada udang vaname. Jurnal Akuakultur Indonesia, 13(1), 11-20.

Widiastini, T. A., Sakinah, E. N., Nurdian, Y., \& Firdaus, J. (2018). Type 3 Resistant Starch Effect of Cassava (Manihot esculenta Crantz) on Fasting Blood Glucose in Diabetes Mellitus Wistar Rat Models. Journal of Agromedicine and Medical Sciences, 4(3), 133. https://doi.org/10.19184/ams.v4i3.6469

Yono, J. M., Yu, K., Donaldson, G. P., Shastri, G. G., Ann, P., Ma, L., Nagler, C. R., Ismagilov, R.F., Mazmanian, S. K., \& Hsiao, E. Y. (2015). Indigenous bacteria from the gut mi- crobiota regulate host serotonin biosynthesis. Cell, 161(2), 264-276.

Zaman, S. A., \& Sarbini, S. R. (2016). The potential of resistant starch as a prebiotic. Crit Rev Biotechnol, $36(3)$, 578-584. https://doi.org/10.3109/07388551.2014.993590.

Zhang, C., Zhang, M., Wang, S., Han, R., Cao, Y., Hua, W., Mao, Y., Zhang, X., Pang, X., Wei, C., Zhao, G., Chen, Y., \& Zhao, L. (2010). Interactions between gut microbiota, host genetics and diet relevant to development of metabolic syndromes in mice. ISME J, 4(2), 232-241.

Zhang, L., Li, H. T., Shen, L., Fang, Q. C., Qian, L. L., \& Jia, W. P. (2015). Effect of dietary resistant starch on prevention and treatment of obesity-related diseases and its possible mechanisms. Biomedical and Environmental Sciences, 28(4), 291-297. https://doi.org/10.3967/bes2015.040

Zhang, Y., \& Zhang, H. (2013). Microbiota associated with type 2 diabetes and its related complications. Food Science and Human Wellness, 2(3-4), 167-172. https://doi.org/10.1016/j.fshw.2013.09.002

Zhao, L. (2013). The gut microbiota and obesity: from correlation to causality. Nat. Rev. Microbiol, 11(9), 639-647.

Zhou, Y., Wei, Y., Yan, B., Zhao, S., \& Zhou, X. (2020). Regulation of tartary buckwheat-resistant starch on intestinal microflora in mice fed with high-fat diet. Food Science and Nutrition, 8(7), 3243-3251. https://doi.org/10.1002/fsn3.1601 
Zhu, Y., Dong, L., Huang, L., Shi, Z., Dong, J., Yao, Y., \& Shen, R. (2020). Effects of oat $\beta$-glucan, oat resistant starch, and the whole oat flour on insulin resistance, inflammation, and gut microbiota in high-fat-dietinduced type 2 diabetic rats. In Journal of Functional Foods, 69. https://doi.org/10.1016/j.jff.2020.103939 